Buddhism and TQM: An alternative explanation of Japan's adoption of

\title{
Total Quality Management
}

\author{
Dr Arthur Poropat \\ Department of Management, Griffith Business School, Griffith University, Australia \\ Email: arthur.poropat@griffith.edu.au
}

Dr John Kellett

School of Economics, University of New England, Australia

Email: john.kellett@une.edu.au 


\title{
Buddhism and TQM: An alternative explanation of Japan's adoption of Total Quality Management
}

\begin{abstract}
The relatively rapid adoption of Total Quality Management (TQM) in Japan has been attributed to several causes, including the efficacy of American trainers or the Japanese adoption of Scientific Management techniques before World War II. An alternative reason considers Japanese culture and spirituality as a dominant explanation, but there does not appear to have been a previous, detailed examination of why Japanese spirituality might be compatible with TQM. This article identifies a series of underlying similarities between Japanese Zen Buddhist philosophy and TQM ideas, such as both emphasising empirically-based practices, scepticism about received truth, encouraging continual improvement, and an assumption of change or variation. The implications of these underlying similarities are discussed, as well as suggestions for future research.
\end{abstract}

\section{KEYWORDS}

TQM, Quality, Japan, Spirituality, Zen Buddhism, Culture

\section{INTRODUCTION}

Total Quality Management (TQM) is one of the more important philosophies of management in the late twentieth and early twenty-first centuries. With its emphasis on continual improvement and its claims with respect to productivity, the promises of TQM are significant, and there is mounting evidence that these promises are well-realised in organisations which implement TQM practices (e.g., Douglas \& Judge Jr., 2001; Prajogo \& Brown, 2004; Taylor \& Wright, 2003). 
TQM is, for many, indelibly linked with Japan and Japanese economic successes in the decades after that nation's military defeat in the Pacific war. Discussions of Japanese management as a phenomenon typically refer to TQM as a key component, if not the very core of the Japanese approach (e.g., Keys \& Miller, 1994; McMillan, 1985; Pascale \& Athos, 1982). Some authors have proposed that Japan was uniquely placed to adopt TQM because of Japanese cultural values and its industrial history (Boje \& Winsor, 1993; Ishikawa, 1985). In this article we argue that the relationship between TQM and Japanese culture goes beyond a happy coincidence: rather, TQM has an underlying resonance with Japanese spirituality generally, and Japanese Buddhism in particular, and that it was this resonance which facilitated the ready acceptance of TQM in Japan.

\section{ELEMENTS OF QUALITY IN TRADITIONAL JAPANESE ORGANISATION}

Defeat in the Pacific war took a heavy toll on Japan, with more than one and a half million military personnel and somewhere between one- and two-thirds of a million civilians killed (Kodansha Encyclopedia of Japan, 1983, vol 6: 224; Walton, 1989: 10). Such a substantial loss of population (Japan's total population was around 70 million at the time) is significant in its own right, but Japan also lost a third of its agricultural production and virtually all of its advanced industries (Walton, 1989: 10). Japan's condition became a matter of serious concern for the government of the United States of America, which was overseeing the occupation and reconstruction of Japan. This was because a weakened Japan was unable to act as a bulwark against US strategic competitors, such as the communist states of the USSR and, after 1949, the People's Republic of China (Khoo \& Tan, 2003; Yoshikazu, 1987: 201-211). Consequently, the US occupying forces took active steps to assist Japan to rebuild its economy, through both economic reforms and industrial development.

Among the steps taken to revitalise Japanese industry was a substantial effort aimed at re-training Japanese workers and managers, including training in the statistical techniques that came to be seen as the foundation of TQM. However, Japanese managers were not ignorant savages, awaiting the 
missionaries of American management - much that the Japanese adopted was entirely consistent with their pre-existing industrial systems (Schroeder \& Robinson, 1991). For example, there is considerable evidence that many people in Japan were already advocates of the statistical procedures associated with TQM (cf.: Noguchi, 1995; Tsutsui, 1996). Joseph Juran himself stated that the credit for TQM in Japan, accorded to him by some American writers, was 'ludicrous', and instead emphasised the special abilities of the Japanese nation (Bowles \& Hammond, 1991). Indeed, there appears to have been much re-writing of history to emphasise the importance of American management thinkers, perhaps to assuage the dented pride of American writers in reaction to Japanese economic resurgence (Boje \& Winsor, 1993).

Instead, much of TQM's popularity in Japan appears to have been due to the fact that TQM is in part a 'neo-modernist' re-statement of Scientific Management (also known as Taylorism), and Japanese business leaders were well-versed in Scientific Management, which was introduced into Japan in the 1920s (Boje \& Winsor, 1993). The introduction of Scientific Management had been facilitated by the simultaneous introduction of practices designed to cultivate company loyalty (training programmes, retirement funds etc). In turn, these practices 'were purposefully designed to invoke the Samurai tradition of constant learning, training and the village tradition of mutual help' (Boje \& Winsor, 1993: 59). Entering onto this background in 1950, TQM's popularity with business leaders, and its acceptability to workers, was made much more likely (Varley, 1974). Put simply, Japan was heading towards quality before quality advocates like the American experts, Edwards Deming and Joseph Juran, headed towards Japan.

Nevertheless, the speed and extent of the adoption of TQM in Japan is noteworthy, especially when these same ideas took much longer to take hold in the United States, despite having originated there. Thus, it is not surprising that some writers sought historical explanations linked to the American occupation of Japan, even though this ignored the longer historical context of Japanese industrial development. Instead, the question about the rate of adoption of TQM in Japan (as compared with other advanced economies, such as the USA and Great Britain, or the similarly defeated Germany) 
should be considered in relation to a wider range of influences than those represented by American post-war activities.

It has been argued elsewhere that Japan was culturally ready for TQM (Khoo \& Tan, 2003; Wilkinson, Redman, Snape, \& Marchington, 1998), in the sense that many Japanese values appear to be particularly consistent with the admonitions of TQM advocates. For example, the Japanese traditions of fine craftsmanship and attention to detail, as exemplified in the practices of miniaturisation, ikebana and the tea ceremony, may have made the Japanese more receptive to Deming's ideas about reduction of wastage, and about how to reliably and consistently manufacture products of high quality (Juran 1993, cited in (Lillrank \& Kano, 1989): 20). Likewise, because of the large number of people who lived in a relatively small area, the Japanese 'may have had a cultural predisposition' for cooperation, which is one of the central ideas in Deming's TQM philosophy (Wilkinson et al., 1998: 84). The Japanese appear to have had a 'penchant for numbers' (Crump, 1992, cited in Drummond, 1992: 20), as exemplified by their adoption of Sudoku, easing the adoption of statistics and the quantification of variation. Even the TQM focus on employees providing suggestions for continuous improvement (Schroeder \& Robinson, 1991) is consistent with Japanese use of suggestion systems as far back as the early eighteenth century (Robinson \& Stern, 1995: p. 139). Clearly, TQM was not as radical a change of mindset for Japanese companies as it appears to have been for organisations in the West.

Given these points, it is tempting to argue that Japan's cultural readiness for TQM may have been little more than a series of convenient cultural coincidences, resulting in TQM being more compatible with Japan than with comparable economies. However, cultural values do not exist in isolation; one cannot separate values from societal institutions, norms and beliefs, nor can one simply alter values without simultaneously altering other aspects of a society (Erez \& Gati, 2004). A major underlying and unifying influence on Japanese culture has been the nation's unique spirituality, which is integrated into everyday life to an extent not paralleled in the West (Chia, 2003; Reader, Andreasen, \& Stafansson, 1993). Just as the adoption of Scientific Management ideas was facilitated by recasting 
them to be more consistent with the Samurai tradition, so the integration of TQM into Japanese thinking appears to have been aided by links between TQM and Japanese spirituality. This is not a new idea: one of the leading thinkers in the Japanese quality movement, Kaoru Ishikawa, stated that Buddhist thinking was one of the main reasons for the success of the TQM philosophy in Japan (Ishikawa, 1990). However, it appears that no previous writers, at least in the English-speaking world, have taken the time to consider the underlying similarities between Buddhist thought and TQM. In this article it is argued that not only are there many parallels between these schools of thought, but also that these parallels were both consciously and unconsciously used to facilitate the adoption of TQM in Japan.

\section{THE DEVELOPMENT OF JAPANESE SPIRITUALITY}

To establish this argument it is necessary to firstly describe the role of Japanese spirituality within Japanese culture. Despite the radical changes the nation has seen in the past 200 years, Japan retained a respect for its religious foundations, so that Buddhism, Confucianism and Shinto remain central to Japanese religious practice. Most modern Japanese profess adherence to two, or even three of these religions, although adherence usually means participation in rituals, rather than philosophical/theological adherence to a set of doctrines (Reader et al., 1993: 33). Yet this is more than a merely formalistic commitment: Zen Buddhism, in particular, remains an important subtext within Japanese education, providing one of the major frameworks for guiding not only development through childhood, but throughout one’s life (Durlabhji, 1993; Reader et al., 1993: 42).

Japan's original religious tradition, Shinto, was and remains the religion of the Imperial Court. The central feature of Shinto is its 'animistic belief in the Kami spirits that fill the world, inhabiting living things as well as mountains, rocks, streams, and so forth' (Reader et al., 1993: 6). This belief dominates Shinto practice, leading to a strong concern with pollution and rituals of purification (Reader et al., 1993: 34). The Chinese philosophy, known in the West as Confucianism, came to 
Japan in the sixth century and its hierarchical understanding of social order remains a primary influence on social ethics and the norms of daily relationships and behaviours (Varley, 1974: 39). Together, Shinto and Confucianism led to an understanding of the Emperor as the father figure chosen by the gods, while the citizens of Japan were members of a divinely chosen and privileged family, whose role was to serve the state (Reader et al., 1993: 39; Varley, 1974: 209). The consequences of this for Japanese culture included an acceptance of discipline and an active support of formal power structures, both within the broader society and as expressed within organisational forms.

Buddhism, also came to Japan in the sixth century, but did not become a popular religion until the Kamakura Period (1185-1333), when it was popularised as a religion of salvation (Pascale \& Athos, 1982). In Japanese Buddhism, much emphasis was placed on the teaching that all beings could attain Buddhahood or enlightenment, not just those who had the resources and temperament to follow specific rituals (Pascale \& Athos, 1982). Another distinct feature of Japanese Buddhism is the fact that it emphasises compassion and reverence for life, rather than suffering and reincarnation. This period coincided with the development in China, Korea and later Japan of the version of Buddhism known in the West as Zen, which became one of the dominant forms of Buddhism in Japan (Reader et al., 1993: 35-37). This particular approach to Buddhism promotes a viewpoint that emphasises the acceptance of transience, with life being seen as constant movement rather than a place or destination to be achieved. Zen also emphasises the use of meditation for attainment of mental discipline that is essential for effective study (Keys \& Miller, 1994).

These multiple religious traditions of Japan have led to neither religious conflict as observed between Protestant and Catholic, nor the syncretism of ancient Hinduism or modern Vodou (Voodoo). Instead, Japan developed a spiritual division of labour, with Confucianism acting as the source of ethics, Western scientific method answering questions of truth, Buddhism accounting for metaphysics and individual learning and development, while aesthetic enquiry is conducted through a Shinto frame-ofreference (Reader et. al., 1993). On a day-to-day basis, Shinto deals with 'rituals of fertility, 
purification, rites of passage and growth, and Buddhism concerns itself with illness, death, enlightenment and education' (Reader et. al., 1993: 42).

Japanese spirituality did not survive the second world war unscathed. Defeat resulted not only in the destruction of Japan's military and economic systems, but also damaged the Japanese people's spiritual system. For example, the state religion of Shinto had provided one of the rationales for Japanese military aggression: Japan was the chosen land of the gods, the Emperor was divine, so defeat was not possible. Japan's defeat and the Emperor's public denial of divine status after that defeat was spiritually troubling. Despite this, the spiritual underpinnings of Japanese culture seem to have survived, with Zen Buddhism, in particular, still underlying much of Japanese education (Durlabhji, 1993). Thus, Zen Buddhism retains a strong influence on Japanese ideas and values, and the culture generally.

\section{JAPANESE SPIRITUALITY AND TQM}

At a surface level, there are some fairly obvious parallels between how Buddhist thought and TQM are presented. The core insights of Buddhism are encapsulated in the four noble truths which are enacted through the eightfold path, whereas Deming proposed a 'system of profound knowledge' made up of four components (Deming, 1994) as well as a broader set of guides for action known as the fourteen points (Deming, 1986). The common emphasis of these disciplines on four basic principles that are enacted through a list of practices presents an interesting similarity of form in the respective teachings. However, the use of simple lists is a common method used by teachers throughout history to aid memory, a particularly venerable example being the Ten Commandments. Certainly, Deming was not the first to produce or use lists in this way, although it may have been that he was influenced by Japanese approaches to presenting ideas. For example, within his first few years in Japan Deming sought to find presentation methods that would make it easier for the Japanese to understand and adopt the quality mind-set, as he understood it. As it happens, Deming's 14 points 
were not presented in Japan but were purely developed for American managers (Noguchi, 1995). Consequently, these formal similarities Deming's presentation of quality and Buddhist teaching practices are at most interesting but not surprising. Other surface level similarities between Buddhism and TQM include the acceptance of the master or enlightened one (Buddha - Deming/Juran etc), the sense that there is an underlying law, rule or way to be followed (Dharma/Truth - Variation etc), and the encouragement of a collective response and cooperation (Sangha/Community - Quality Circles, etc). Again, these parallels are relatively common-place and it would be difficult to think of many schools of thought which do not have comparable elements.

However, TQM does share some basic, non-trivial features with Buddhism. To begin with, TQM is an empirical management philosophy, which encourages managers to focus on direct evidence rather than assumed knowledge (Kujala \& Lillrank, 2004). The corollary of this is that one must forever remain unconvinced that accepted practices are beyond improvement. Deming, for example, drew much of his philosophical basis from the early $20^{\text {th }}$ century philosopher Lewis, who argued for a position in which the only knowledge of the world is of the probabilities of various events, and hence one must be sceptical of all knowledge (Petersen, 1997). These points are entirely consistent with Zen Buddhism, which renounces any form of dogmatic (or intellectual) mediation between experience and insight. Instead, a Zen practitioner approaches enlightenment by means of observation and experience, making Zen a highly empirical philosophy which stresses direct experience and action (Walton, 1989). This is exemplified in the Zen saying, “If you see the Buddha in the road, slay him!” - in other words, anything that claims to be indubitable and reliable is misleading and must be disposed of. Thus, the basic philosophical positions of both Zen Buddhism and TQM have a similar basis with respect to how one comes to know about the true nature of things, and the extent to which one should be sceptical about dogmatic positions.

For Buddhists, scepticism about the world also applies to the self, so any categorical statements about one's self are viewed with suspicion. A logical extension of this is the belief that satisfaction with one's achievements, the sense of 'having arrived', represents a form of self-delusion and is somewhat 
morally repugnant (Chia, 2003). Within Japanese culture the imperfectness of life, the view that nothing is ever completely satisfactory, is a basic assumption. This is implied by the first of the Buddhist Four Noble Truths - suffering is inherent in life. Acceptance of this belief, however, is not seen as nihilistic, but rather is considered to be a prompt for cultivating oneself. From this perspective, feelings of satisfaction should be avoided, because they are an illusion that detracts from selfcultivation. This attitude has been used as an explanation for the fact that Japanese workers typically report lower levels of job satisfaction than do their Western counterparts (Stupak, 1999). From this perspective, self-criticism is highly valued because it directs a person away from misleading and premature acceptance of partial insights which would stand in the way of achieving enlightenment. This humble but relentless striving for perfection is exemplified in the Zen art of archery, and also in the Buddhist emphasis on life-long learning (Tsuda \& Tribus, 1985). Such spiritual questing can be compared with organisational activities such as Kaizen (often translated as 'continuous improvement'), which is directly linked to Zen Buddhism, even though the zen part of Kaizen does not have the same origin as the word Zen for Buddhism. Instead, the zen in Kaizen refers to the practice of good or benefit in an impersonal manner, while kai refers to efforts made to create change. Hence, Kaizen is about improvement, but is typically taken to mean an ongoing effort at achieving impersonal benefits (Lincoln, 1989). This unending pursuit of impersonal virtue is nonetheless informed by the Zen emphasis on continuously striving for enlightenment (Stupak, 1999: p. 428), but is also quite consistent with the TQM emphasis on unendingly reducing variation.

Continual improvement, by means of the Plan-Do-Check-Act cycle or other methodologies, is a cornerstone of TQM, which assumes that every improvement is just a step on the path of greater control of variation, and that accepting a certain level of variation places one in a vulnerable position; there is never a good-enough level of quality. Thus the TQM emphasis on gradual but relentless increments in quality found a ready audience in Japanese managers who had grown up assuming that relentless improvement is morally correct. Given the similar assumptions in Buddhism and TQM about relentless striving, it is not surprising that several authors have concluded that TQM 
management in general, and the Plan-Do-Check-Act cycle in particular, are particularly compatible with Japanese culture (Khoo \& Tan, 2003; Watt, 1982).

Continual improvement is not just about systems - it is also about self-improvement and continual learning. The emphasis on training and development in Japanese management (Keys \& Miller, 1994), and in Deming's recommendations (Deming, 1986), is consistent with the Zen emphasis on unrelenting training of both the mind and body. For example, the military tradition of fencing was incorporated into Zen practice, but with an emphasis on continually improving and refining one's technique, with the goal of integrating mind, body and activity. The end result is a sense of effortless activity. Thus meditation and other Zen practices became ways of successively approaching the goal of no-mind, or transcendence of the individual ego (Suzuki, 1959). The achievement of this goal requires a single-minded determination, a resolute dedication to this purpose, words that echo phrases readily used by quality practitioners.

One of the few things which Japanese Buddhism presents as certain is the transient nature of reality and the unavoidability of change. This emphasis on the impermanence of life and the importance of constant striving for enlightenment are seen by some as consistent with and promoting of a continual quest for improvement (Fry, 1991) and an emphasis on planning for the long term (Keys \& Miller, 1994). However, the Buddhist idea that things inevitably change is also not far removed from the TQM assumption that variation is ubiquitous. Within TQM, quality is defined by conformance to standards, and defects are variations from specified standards (Deming, 1986), and most, if not all, of the activities associated with TQM address the issue of variation directly or indirectly. For example, Quality Assurance procedures are designed to standardise systems and processes in order to reduce variation, control charts are used to monitor levels of variation, and pareto charts provide insights as to which sources of variation might be most profitably addressed. So both Buddhism and TQM pay much attention to the ways that things change. 
It may be argued, that there are differences between Buddhist transience and the TQM concept of variation. To begin with, while they both highlight limits of human ability to control the world, variation has a precise statistical meaning, whereas awareness of transience is more of a qualitative understanding. A more important difference lies in the responses made to these ideas. Over the centuries, Zen Buddhism has come to accept transience as something to be appreciated in itself; for the Japanese, transience is seen as crucial to beauty (Heine, 1991). As the Buddhist mystic Kenko put it, “The most precious thing in life is its uncertainty” (cited in Heine, 1991: 402). This contrasts with the valiant efforts of TQM practitioners to relentlessly confront and reduce variation, especially those who have adopted the goal of achieving Six Sigma, which involves the reduction of variation to progressively smaller proportions. Nonetheless, both transience and variation betray a fundamental belief in, and a deep respect for, the unpredictability of existence.

From a darker perspective, the aforementioned efforts of TQM practitioners to address the problem of variation can at times can appear obsessive to observers, as anyone who has experienced being on the receiving end of a quality assurance program can testify. This fervour has been described by several writers as a form of advanced managerialist control of the workforce, a statistically-based effort to subjugate or trivialise workers' interest (Boje \& Winsor, 1993; e.g., Mallinger, 1993). Although these critics of TQM do provide evidence of TQM being used consciously or unconsciously as a tool of worker exploitation, this does not mean that there is not an ethical aspect to TQM that comes through in the writings of practitioners. Indeed, some practitioners describe their understanding of TQM in terms that appear straightforwardly religious. For example, consider the following quote written to Deming by one of his friends:

At the heart of your message there is an exhortation to shift from an upward focus, self aggrandizing in its aim, to an outward, altruistic focus. We stop seeking to please ourselves and seek to please customers and those in our companies who deserve to be proud of their work and find joy in it. A shift from greed to caring (quoted by Petersen, 1997: p. 116).

Despite the evidence that TQM tends to benefit shareholders at the expense of workers (cf., Mallinger, 1993; Parker \& Slaughter, 1993), there is an enduring belief among TQM practitioners that 
they are making the world a better place. It is not putting it too strongly to say for that for many, especially Deming, TQM is part of one's spiritual mission in life, an expression of a sense of compassion to fellow humans (Greisler, 1999).

Buddhists too have a clearly ethical component that flows from their appreciation of the world indeed, compassion towards all sentient beings is a basic Buddhist virtue and considered a normal outgrowth of awareness. The Buddhist eight-fold path is seen by many as a guide for ethical behaviour and engagement with the problems of the world (White, 1999). Just like with TQM, however, some practitioners have used Buddhism as a cover for less noble outcomes, including financial and sexual misdeeds (Brown, 1999) - Buddhism too has skeletons in its closets. Both Buddhism and TQM have developed ethical positions on the back of an appreciation of change in life, but this alone does not appear to be enough to prevent some from debasing what on the surface appear to be positive paradigms.

This comparison of TQM and Buddhism, particularly Zen Buddhism, concludes with a subtle point — the difficulty of saying precisely just what either Buddhist enlightenment or TQM really are. Zen Buddhism is replete with stories of the inherent undefinability of the goal of Zen (Suzuki, 1968). Likewise, the meaning of TQM is far from obvious. Amongst TQM scholars there is much ambiguity, for a range of good reasons, as described by Wilkinson et al (1998). Firstly, TQM and the concept of quality are, in themselves, difficult to define. 'TQM means different things to different consultants' (Boje, 1993: 5), and even Edwards Deming, when asked to define TQM stated that "I do not know what TQM is" (Boje, 1993: 4). The range of definitions that have been proposed include 'Zero defects', 'right first time' and 'fitness for use', which although distinct appear to have an underlying, if elusive, unity (Hackman \& Wageman, 1995). Secondly, the variety of activities, programs, tools and techniques which are used by TQM practitioners is so broad that TQM appears to have a different face with each implementation. Advocates of TQM embrace this ambiguity as a virtue - it means that TQM is malleable, and can be tailored to individual beliefs and needs. Despite this difficulty of definition TQM is sufficiently different from other managerial theories and practices to allow us to 
differentiate and identify it (Wilkinson et al., 1998). So, just like Zen, TQM is resistant of definition, if not actually indefinable.

\section{CONCLUSION}

In this article we have put forward evidence that the underlying philosophy of TQM has several nontrivial parallels with the ideas of Zen Buddhism, one of the major spiritual traditions which informs much of Japanese culture. Whereas most world religions are faith-based, such as Christianity, Islam and Judaism, Zen Buddhism has a radical empirical basis which is entirely consistent with the heavily empirical methodologies advocated by TQM practitioners. Buddhist scepticism about the world and the self drives a relentless striving for self-improvement that has clear parallels with the TQM emphasis on continual improvement in organisations. The cornerstone TQM, the understanding of the ubiquity of variation, is echoed by the Buddhist emphasis on transience and change. Both traditions use their philosophy as the basis for a broader ethical program of behaviour in the world, even though both have, at times, been shown to have feet of clay. Even the degree to which each tradition is resistant of neat, unambiguous definition is similar. Clearly, Zen Buddhism and TQM have much in common, despite their disparate origins.

What has been presented in this article is a long way from arguing that TQM and Zen Buddhism are synonymous. One has merely to consider the main focus of each tradition, one being a theory of organisation management, the other a metaphysical and spiritual guide for individual enlightenment, to recognise this profound differences between them. Yet there are similarities at a fundamental level between these traditions that are more than casually interesting and that go a considerable way towards explaining the Japanese affinity for TQM. After all, adopting TQM within an organisation requires a substantial change of organisational culture (Wilkinson et al., 1998). Cultural change is a complex, difficult and fraught process. If an organisation is composed of people who were brought up with many of the basic assumptions of the changes which are being implemented, the process of 
change is likely to be considerably easier. One of the conclusions that follows from the arguments presented in this article are that TQM change agents were, in effect, teaching people who understood Buddhist assumptions how to put those assumptions into practice within their organisation. If this is so, it is no wonder that Japan appears to have had a particular affinity for TQM.

Given that both TQM and Zen Buddhism have a decidedly practical bent, it is reasonable to expect that this analysis of their association should conclude with some practical implications. If TQM and Zen Buddhism have as much in common as has been argued here, and this commonality facilitated the adoption of TQM within Japan, there should be similar outcomes in different settings and with different levels of analysis. To begin with, other countries should differ in their ability to adopt TQM to the extent to which their cultures and educational systems are informed by Buddhist thought as opposed to other religious traditions. It would be instructive, therefore, to consider the ease with which Thailand, a largely Buddhist country, adopted TQM when compared with his close neighbours, the largely Muslim Malaysia and Indonesia, or the largely Catholic Philippines. On the basis of this article one would expect Thailand to adapt to TQM more readily. On the other hand, it should also be expected that individual companies, which had more Buddhist employees and managers, would adopt TQM more readily. Both of these propositions are empirically testable and do not seem to have been previously researched.

This examination of underlying cultural assumptions also has implications for the study of national culture and its influence on organisations. As useful as Hofstede's (1997) five dimensions for comparing culture is, the knowledge that Japanese culture is high on uncertainty avoidance, long-term orientation and masculinity, but middling on collectivism and power distance, does not clearly imply the Japanese penchant for TQM. Yet the examination of the spiritual assumptions of Japanese culture seems to have quite specific implications. It may prove useful for future cultural researchers to consider analysing underlying spiritual assumptions for compatibility with management philosophies as a way of predicting the outcomes of organisational interventions, especially TQM implementation. 
A culture's basic assumptions can have profound effects, but also appear to be resistant of change. In the Japanese context, Reader et al (1993) stated this very clearly:

' ... one of the most remarkable features of Japanese life is that, while so much has changed, there remains a sense of underlying stability, both in the social system and within Japanese culture. The religious ethos itself has been a major influence here ... there is a sense of continuity that has helped give people a source of strength and stability with acts as a balance to the increasing speed of change in other aspects of life' (13).

This culture has been a source of strength for Japan, but it appears that, at times, the spiritual underpinnings of a culture not only act to balance pace of modern life - at times it may actually facilitate change. This appears to be the role that Zen Buddhism took in preparing a path for the implementation of TQM into Japan.

\section{REFERENCES}

Boje, D. M. (1993). Editorial: Post TQM. Journal of Organizational Change Management, 6(4), 4-8.

Boje, D. M., \& Winsor, R. D. (1993). The resurrection of Taylorism: Total quality management's hidden agenda. Journal of Organizational Change Management., 6(4), 57-70.

Bowles, J., \& Hammond, J. (1991). Beyond Quality. New York: G.P. Putnam's Sons.

Brown, M. (1999). The spiritual tourist: A personal odyssey through the outer reaches of belief. London: Bloomsbury.

Chia, R. (2003). From knowledge-creation to the perfecting of action: Tao, Basho and pure experience as the ultimate ground of knowing. Human Relations, 56(8), 953-981.

Deming, E. W. (1986). Out of the crisis. Cambridge, Mass.: Massachusetts Institute of Technology, Center for Advanced Engineering Study.

Deming, E. W. (1994). The new economics: For industry, government, education. (2nd ed ed.). Cambridge, Mass.: Massachusetts Institute of Technology, Center for Advanced Engineering Study. 
Douglas, T. J., \& Judge Jr., W. Q. (2001). Total quality management implementation and competitive advantage: The role of structural control and exploration. Academy of Management Journal, 44(1), 158-169.

Drummond, H. (1992). The Quality Movement: What Total Quality Management is really all about. London: Kogan Page.

Durlabhji, S. (1993). The influence of Confucianism and Zen on the Japanese organization. In S. Durlabhji \& E. Norton (Eds.), Japanese business: Cultural perspectives.

Erez, M., \& Gati, E. (2004). A dynamic, multi-level model of culture: From the micro level of the individual to the macro level of a global culture. Applied Psychology: An International Review, 53(4), $583-598$.

Fry, E. (1991). Subtlety and the art of Japanese management. Business Credit, 93(9), 26-28.

Greisler, D. S. (1999). William Edwards Deming: The man. Journal of Management History, 5(8), 434-453.

Hackman, J. R., \& Wageman, R. (1995). Total quality management: Empirical, conceptual, and practical issues. Administrative Science Quarterly, 40(2), 309-342.

Heine, S. (1991). From rice cultivation to mind contemplation: The meaning of impermanence in Japanese religion. History of Religions, 30(4), 373-403.

Hofstede, G. (1997). Cultures and organizations: Software of the mind. New York: McGraw-Hill. Ishikawa, K. (1985). What is Total Quality Control - The Japanese way. New York: Prentice-Hall. Ishikawa, K. (1990). Introduction to quality control. Tokyo: 3A Corporation.

Keys, J. B., \& Miller, T. R. (1994). The Japanese management theory jungle - revisited. Journal of Management, 20(2), 373-402.

Khoo, H. H., \& Tan, K. C. (2003). Managing for quality in the USA and Japan: Differences between the MBNQA, DP and JQA. The TQM Magazine, 15(1), 14-24.

Kujala, J., \& Lillrank, P. (2004). Total quality management as a cultural phenomenon. Quality Management Journal, 11(4), 43-55.

Lillrank, P., \& Kano, N. (1989). Continuous improvement: Quality control circles in Japanese industry. Ann Arbor: Centre for Japanese Studies, University of Michigan. 
Lincoln, J. R. (1989). Employee work attitudes and management practice in the US and Japan. California Management Review(Fall), 89-106.

Mallinger, M. (1993). Ambush along the TQM trail. Journal of Organizational Change Management, 6(4), 30-42.

McMillan, C. J. (1985). The Japanese Industrial System. New York: Walter de Gruyter.

Noguchi, J. (1995). The legacy of W. Edwards Deming. Quality Progress, 28(12), 35-37.

Parker, M., \& Slaughter, J. (1993). Should the labour movement buy TQM? Journal of Organizational Change Management, 6(4), 43-56.

Pascale, R., \& Athos, A. (1982). The Art of Japanese Management. Harmondsworth: Penguin.

Petersen, P. B. (1997). Library of Congress archives: additional information about W. Edwards Deming (1900-1993) now available. Journal of Management History, 3(2), 98-118.

Prajogo, D. I., \& Brown, A. (2004). The relationship between TQM practices and quality performance and the role of formal TQM programs: An Australian empirical study. Quality Management Journal, 11(4), 31-42.

Reader, I., Andreasen, E., \& Stafansson, F. (1993). Japanese religions: Past and present. Honolulu: University of Hawaii Press.

Robinson, A. G., \& Stern, S. (1995). Strategic national HRD initiatives: Lessons from the management training program of Japan. Human Resource Development Quarterly, 6, 2; ABI/INFORM Global

pg. 123(2), 123-147.

Schroeder, D. M., \& Robinson, A. G. (1991). America's most successful export to Japan: Continuous improvement programs. Sloan Management Review, 32(3), 67-81.

Stupak, R. J. (1999). Symposium introduction: An operational code approach to W. Edwards Deming

- The man, the context, the savant and the legacy. Journal of Management History, 5(8), 428-433.

Suzuki, D. T. (1959). Zen and Japanese Culture. Princeton: Princeton University Press.

Suzuki, D. T. (1968). The essence of Buddhism. (2nd ed.). Kyota: Hozokan.

Taylor, W. A., \& Wright, G. H. (2003). A longitudinal study of TQM implementation: Factors influencing success and failure. Omega, 31, 97-111. 
Tsuda, Y., \& Tribus, M. (1985). Managing for quality: Does culture make a difference? Quality Progress(November), 23-29.

Tsutsui, W. M. ( 1996). W. Edwards Deming and the origins of quality control in Japan. The Journal of Japanese Studies, 22(2), 295-325.

Varley, H. P. (1974). Japanese culture: A short history. Tokyo: Charles E Tuttle Company.

Walton, M. (1989). The Deming management method: With an introduction by Dr Deming. London: Mercury Books.

Watt, P. (1982). Shinto and Buddhism: Wellsprings of Japanese spirituality. Asia Society's Focus on Asian Studies, 2(1), 21-23.

White, J. (1999). Ethical comportment in organizations: A synthesis of the feminist ethic of care and the Buddhist ethic of compassion. International Journal of Value-Based Management, 12(1), 109128.

Wilkinson, A., Redman, T., Snape, E., \& Marchington, M. (1998). Managing with Total Quality Management: Theory and practice. Basingstoke: Macmillan.

Yoshikazu, S. (1987). The international context of the occupation of Japan. In R. E. Ward \& S. Yoshikazu (Eds.), Democratizing Japan: The Allied occupation. Honolulu: University of Hawaii Press. 